\title{
A new species of Astyanax (Ostariophysi: Characiformes: Characidae) from the upper rio Iguaçu basin, southern Brazil
}

\author{
Leonardo F. S. Ingenito and Luiz F. Duboc
}

Astyanax eremus, a new species of geographically isolated characid fish, is described from a small tributary of the upper rio Iguaçu basin. The new species belongs to the Astyanax scabripinnis species complex and is easily distinguished from its congeners included in this group by its allometric growth of the mouth, which goes from terminal in young individuals to subterminal mouth in larger specimens. Additionally, the new species is distinguished by meristic and morphometric characters. Astyanax eremus presents an evident polymorphism on the traditional character "number of teeth in inner premaxillary row". Comments about that character are provided.

Astyanax eremus, uma espécie nova de caracídeo geograficamente isolada, é descrita de um pequeno tributário da bacia do alto rio Iguaçu. A espécie nova pertence ao complexo de espécies Astyanax scabripinnis e é facilmente distinguível dos congêneres deste grupo por apresentar desenvolvimento alométrico da boca, a qual passa de terminal nos indivíduos jovens a subterminal nos maiores. Além disso, a espécie nova é diagnosticada por caracteres merísticos e morfométricos. Astyanax eremus apresenta um acentuado polimorfismo do tradicional caráter "número de dentes da série interna do pré-maxilar". Uma discussão a respeito deste caráter é apresentada.

Key words: Neotropical region, Astyanax scabripinnis species complex, Systematics, rio Paraná basin.

\section{Introduction}

Astyanax Baird \& Girard is one of the most widespread and species rich characid genus, comprising more than two hundred nominal and over a hundred valid species occurring from Texas (United States of America) to Argentina and Uruguay (Lima et al., 2003; Eschmeyer \& Fricke, 2013). The monophyly of the genus is widely rejected at its current composition, being considered a polyphyletic or paraphyletic group (Weitzman \& Malabarba, 1998; Calcagnoto et al., 2003; Javonillo et al., 2010; Mirande, 2010; Oliveira et al., 2011), what requires robust revisionary and phylogentic studies about the genus.

The single revisionary study concerning Astyanax was carried out by Eigenmann $(1921,1927)$. His study is still the main and wider attempt to clarify the systematics of the genus. Eigenmann's definition of Astyanax is composed by a combination of non-apomorphic nor exclusive characters: premaxillary teeth in two rows, posterior row of premaxilla bearing five teeth, complete lateral line, adipose fin present, and caudal fin naked. Those characters are broadly distributed along characid fishes (Marinho \& Lima, 2009), and seems to be sometimes variable, which lead to doubts in the generic assignment of some characid genera.

During a sample expedition released on 2008 in the upper and middle courses of rio Iguaçu for the CT-HIDRO project (Fundo Setorial de Recursos Hídricos, Conselho Nacional de Desenvolvimento Científico e Tecnológico - CNPq), we discovered a new geographic isolated Astyanax species with variable number of teeth in the inner premaxillary row. The new species is herein described and belongs to the Astyanax scabripinnis species complex sensu Moreira-Filho \& Bertollo (1991), Bertaco \& Malabarba (2001) and Bertaco \& Lucena (2006).

\section{Material and Methods}

Morphological measurements were made point to point, to the nearest $0.1 \mathrm{~mm}$ with electronic caliper, on the left side of the specimens whenever possible. Morphometric and meristic

Programa de Pós-Graduação em Biodiversidade Tropical (PPGBT), Departamento de Ciências Agrárias e Biológicas (DCAB), Centro Universitário Norte do Espírito Santo (CEUNES), Universidade Federal do Espírito Santo (UFES), Rodovia BR-101 Norte, km 60, 29.932-540 São Mateus, ES, Brazil. 1fsi@uol.com.br (LFSI); lfduboc@uol.com.br (LFD) 
data followed Fink \& Weitzman (1974). Counts of vertebrae, branchiostegal rays, gill-rakers, and supraneurals were taken from four cleared and double-stained specimens (c\&s) prepared according to the methodology proposed by Potthoff (1984). Vertebral counts include the Weberian apparatus, counted as four vertebrae, and the compound urostyle, counted as one element. Counts are presented in the text followed by their frequency in parenthesis. An asterisk indicates counts for the holotype. Proportions of the body are expressed as percent of standard length (SL) while proportions of head structures are expressed as percent of head length (HL).

Institutional abbreviations are: DZSJRP, Departamento de Zoologia e Botânica da Universidade Estadual Paulista "Júlio de Mesquita Filho", São José do Rio Preto; MCP, Museu de Ciências e Tecnologia da Pontifícia Universidade Católica do Rio Grande do Sul, Porto Alegre; MHNCI, Museu de História Natural Capão da Imbuia, Curitiba; MNRJ, Museu Nacional, Universidade Federal do Rio de Janeiro, Rio de Janeiro; MZUSP, Museu de Zoologia da Universidade de São Paulo, São Paulo; NUP, Coleção Ictiológica do Nupélia (Núcleo de Pesquisas em Limnologia, Ictiologia e Aquicultura da Universidade Estadual de Maringá), Maringá. All examined specimens are $4 \%$ formalin fixed and $70^{\circ}$ GL ethanol preserved, except those labeled with c\&s, which indicates cleared and double stained specimens preserved in glycerin, and those labeled with DNA, which indicates specimens fixed and preserved in $96^{\circ} \mathrm{GL}$ alcohol for future molecular studies. Comparative material is presented at the end of the text. Additional information about members of Astyanax scabripinnis species complex (Table 1) were obtained from original descriptions, for species described recently (after 2000); data for A. goyanensis (Miranda-Ribeiro), from Bertaco et al. (2010); for A. gymnogenys Eigenmann, from Garavello \& Sampaio (2010); for A. intermedius Eigenmann, from Melo (2001); for A. laticeps (Cope) and A. obscurus (Hensel), from Bertaco \& Lucena (2010); for A. jenynsii (Steindachner), A. rivularis (Lütken), A. scabripinnis (Jenyns), from Melo (2001), Bertaco \& Malabarba (2001), Bertaco \& Lucena (2006, 2010), and Zanata \& Camelier (2009). Complementary data about A. turmalinensis Triques, Vono \& Caiafa were obtained from Triques \& Queiroz (2010).

\section{Astyanax eremus, new species Figs. 1-5}

Holotype. MNRJ 39677, 94.0 mm SL, Brazil, Paraná, Balsa Nova, rio Canivete, at Fazenda Amola-Faca/Registro, tributary to the rio Iguaçu, $25^{\circ} 35^{\prime} 09^{\prime} \mathrm{S} 49^{\circ} 44^{\prime} 01^{\prime \prime} \mathrm{W}, 23$ Oct 2008 , L. F. S. Ingenito, L. F. Duboc \& G. Otto.

Paratypes. MCP 46942, 10, 36.2-99.5 mm SL (2 c\&s, 61.8 $\mathrm{mm}$ SL male, $71.9 \mathrm{~mm}$ SL female). MHNCI 12485, 8, 40.4$79.5 \mathrm{~mm}$ SL (plus 5 in ethyl alcohol, 50.2-89.9 mm SL). MNRJ
Table 1. List of the species included in the Astyanax scabripinnis species complex sensu Bertaco \& Lucena (2006).

\begin{tabular}{ll}
\hline Species & Author \\
\hline Astyanax brachypterygium & Bertaco \& Malabarba, 2001 \\
Astyanax burgerai & Zanata \& Camelier, 2009 \\
Astyanax courensis & Bertaco, Carvalho \& Jerep, 2010 \\
Astyanax cremnobates & Bertaco \& Malabarba, 2001 \\
Astyanax epiagos & Zanata \& Camelier, 2008 \\
Astyanax goyanensis & (Miranda-Ribeiro, 1944) \\
Astyanax guaricana & Oliveira, Abilhoa \& Pavanelli, 2013 \\
Astyanax gymnogenys & Eigenmann, 1911 \\
Astyanax intermedius & Eigenmann, 1908 \\
Astyanax ita & Almirón, Azpelicueta \& Casciotta, 2002 \\
Astyanax jacobinae & Zanata \& Camelier, 2008 \\
Astyanax jenynsii & (Steindachner, 1877) \\
Astyanax jordanensis & Alcaraz, Pavanelli \& Bertaco, 2009 \\
Astyanax laticeps & (Cope, 1894) \\
Astyanax leonidas & Azpelicueta, Casciotta \& Almirón, 2002 \\
Astyanax microschemos & Bertaco \& Lucena, 2006 \\
Astyanax obscurus & (Hensel, 1870) \\
Astyanax ojiara & Azpelicueta \& Garcia, 2000 \\
Astyanax paranae & Eigenmann, 1914 \\
Astyanax paris & Azpelicueta, Almirón \& Casciotta, 2002 \\
Astyanax pirabitira & Lucena, Bertaco \& Berbigier, 2013 \\
Astyanax pirapuan & Tagliacollo, Britzke, Silva \& Benine, 2011 \\
Astyanax rivularis & (Lütken, 1875) \\
Astyanax scabripinnis & (Jenyns, 1842) \\
Astyanax serratus & Garavello \& Sampaio, 2010 \\
Astyanax totae & Haluch \& Abilhoa, 2005 \\
Astyanax troya & Azpelicueta, Casciotta \& Almirón, 2002 \\
Astyanax turmalinensis & Triques, Vono \& Caiafa, 2003 \\
Astyanax varzeae & Abilhoa \& Duboc, 2007 \\
\hline & \\
&
\end{tabular}

39678, 11, 42.2-80.0 mm SL (2 c\&s, $44.6 \mathrm{~mm}$ SL unsexed, $76.2 \mathrm{~mm}$ SL female). NUP 13501, 8, 33.9-86.9 mm SL. All specimens collected with the holotype.

Diagnosis. The combination of shallow body depth (27.3$31.3 \%$ vs. more than $41.0 \%$ of SL), low number of branched anal-fin rays $(16-21$, mean $=18$, vs. more than 21 rays $)$, dark midlateral stripe extending to the tip of the caudal-fin rays, and body heaviest in the area proximate to middle of pectoral fins include Astyanax eremus in the A. scabripinnis species complex of Bertaco \& Lucena (2006). Astyanax eremus is distinguished from all species of the A. scabripinnis species complex by its subterminal mouth in specimens larger than $48.2 \mathrm{~mm} \mathrm{SL}$ (vs. mouth terminal in all species). Additionally, A. eremus is distinguished from all species from this complex, except $A$. guaricana, A. gymnogenys, A. laticeps, A. obscurus, A. paranae, A. pirabitira, A. scabripinnis, A. serratus, and A. varzeae by 


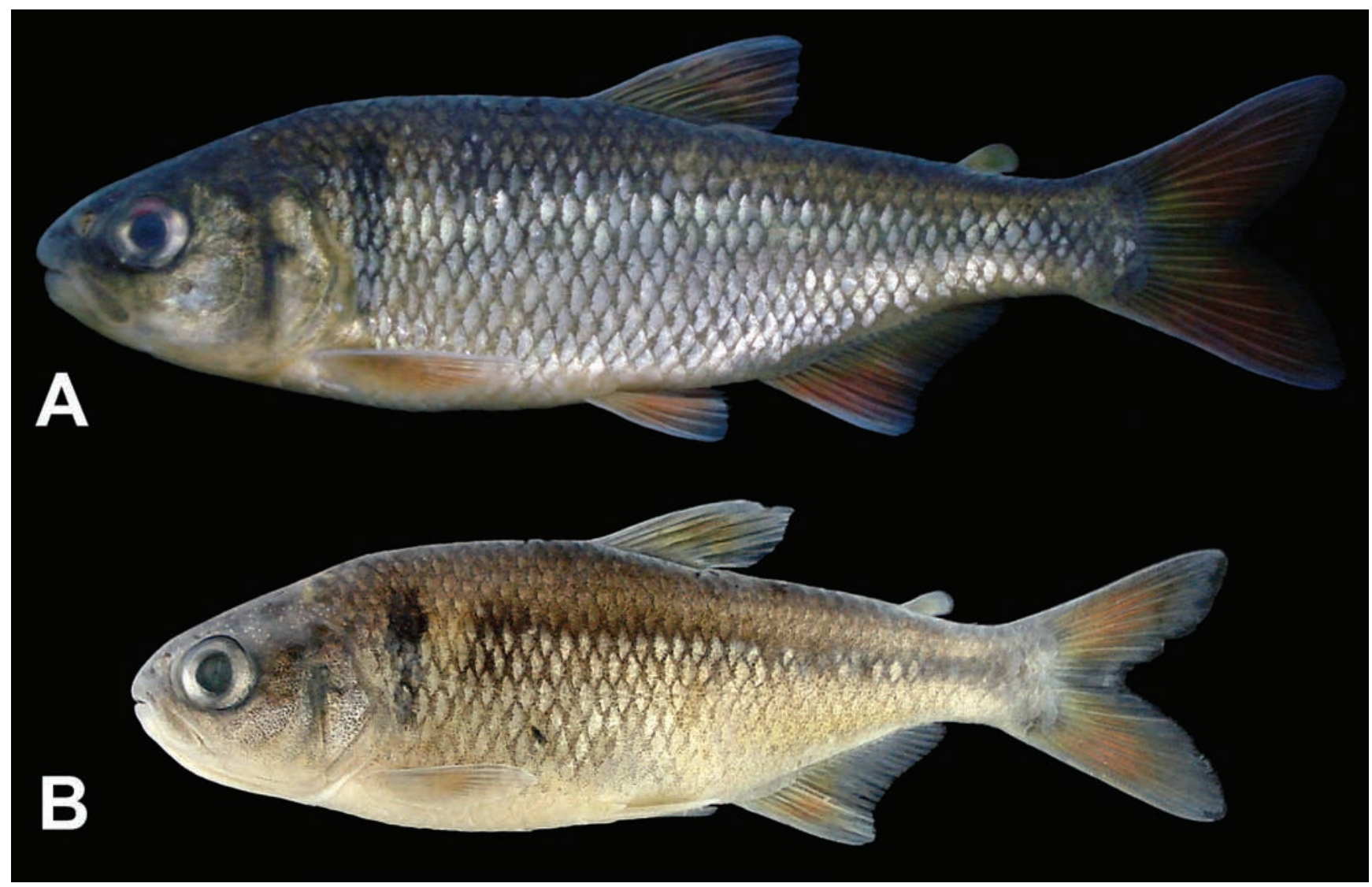

Fig. 1. Astyanax eremus, new species. A: Holotype, MNRJ 39677, 94.0 mm SL; B: Paratype, MCP 46942, 59.9 mm SL. All from the rio Canivete, Balsa Nova, Paraná State, Brazil.

its higher number of lateral line scales (39-41 vs. 31-38). From A. gymnogenys, A. laticeps, A. obscurus, A. scabripinnis and A. serratus, $A$. eremus is distinguished by its shallower body depth (27.3-31.3\% vs. 35.7-39.0\%, 35.3-40.6\%, 31.6-40.8\%, $33 \%$ and $34.2-39.7 \%$ of SL, respectively). Astyanax eremus is distinguished from $A$. paranae by its longer snout length (21.8-26.8\% vs. $16.0-20.4 \%$ of HL). From A. guaricana the new species can be differentiated by its shorter interorbital width (23.5-28.4\% vs. 32.7-40.9\% of HL) and shorter head length (27.1-32.5\% vs. 23.9-26.6\% of SL). From A. varzeae the new species can be differentiated by its shorter interorbital width (23.5-28.4\% vs. 29.8-37.7\% of HL), by relatively shorter caudal peduncle length (13.3-16.3\%, modally $14.9 \%$, vs. 10.5 $13.9 \%$, modally $12.4 \%$, of SL) and relatively longer snout length (21.8-26.8\%, modally $24.5 \%$, vs. $16.4-23.3 \%$, modally $20.1 \%$, of HL). From A. pirabitira the new species is distinguished by the presence of four to five cusps on the second to fourth tooth in the inner premaxillary series (vs. seven cusps). Astyanax eremus also differ from $A$. burgerai, $A$. intermedius, $A$. jacobinae, $A$. leonidas, A. microschemos, A. ojiara, A. turmalinensis, A. laticeps, $A$. obscurus, $A$. pirapuan, $A$. rivularis, $A$. serratus, and A. troya by the shape of humeral spot (straight, very narrow and height, occupying two or two and a half scales wide and about six scales height, vs. wide and short with curved or rounded portions, occupying three or more scales wide and less than six scales height in the former seven species and with upper portion wide and something rounded with a vertical projection in $A$. laticeps, A. obscurus, A. pirapuan, A. serratus, and A. troya).

Description. Morphometric data is given in Table 2. Body compressed. Greatest body depth usually located anterior to dorsal-fin origin. Dorsal profile of head rounded from margin of upper lip to vertical through anterior nostrils, straight or slightly convex from this point to supraoccipital spine. Dorsal profile of body slightly convex between supraoccipital spine and origin of dorsal fin, straight at dorsal-fin origin, slightly convex between dorsal and adipose fins, and gently concave at caudal peduncle. Ventral profile of head and body gently convex from mouth to anal-fin origin, straight to slightly convex at anal-fin base, and gently concave at caudal peduncle.

Mouth subterminal, lower jaw shorter than upper jaw. Mouth of specimens smaller than $48.2 \mathrm{~mm}$ SL almost terminal with equal jaws, becoming gradually subterminal with size increase. Maxillary bone surpassing iris anterior margin, bearing one (4), two (18), three ( $\left.5^{*}\right)$, four (4), or five (2) tri- (31) or pentacuspid $\left(2^{*}\right)$ teeth. Premaxillary teeth in two rows: outer row with three $(7)$ or four $\left(23^{*}\right)$ tri- $\left(28^{*}\right)$ or tetracuspid (1) teeth. Teeth of outer row smaller than those of inner row; aligned and not 
Table 2. Morphometric data of 33 specimens of Astyanax eremus from the upper rio Iguaçu. $\mathrm{SD}=$ Standard deviation. Range includes the holotype.

\begin{tabular}{|c|c|c|c|c|}
\hline & Holotype & Range & Mean & SD \\
\hline Total length $(\mathrm{mm})$ & 113.2 & $43.1-117.7$ & 79.3 & - \\
\hline Standard length $(\mathrm{mm})$ & 94.0 & $33.9-99.5$ & 64.2 & - \\
\hline \multicolumn{5}{|c|}{ Percents of Standard Length } \\
\hline Body depth at dorsal-fin origin & 28.9 & 27.3-31.3 & 29.6 & 1.0 \\
\hline Snout to dorsal-fin origin & 52.1 & $50.8-55.0$ & 52.6 & 1.0 \\
\hline Snout to pectoral-fin origin & 27.4 & 25.7-30.1 & 27.4 & 1.0 \\
\hline Snout to pelvic-fin origin & 51.2 & 49.6-52.9 & 51.5 & 0.9 \\
\hline Snout to anal-fin origin & 66.8 & $64.4-69.0$ & 66.8 & 1.0 \\
\hline Caudal peduncle depth & 10.3 & $8.7-11.0$ & 10.4 & 0.5 \\
\hline Caudal peduncle length & 15.1 & $13.3-16.3$ & 14.9 & 0.7 \\
\hline Pectoral-fin length & 19.3 & $17.7-21.3$ & 19.5 & 0.8 \\
\hline Pelvic-fin length & 14.5 & $13.6-17.1$ & 15.1 & 0.7 \\
\hline Dorsal-fin base length & 12.5 & $10.6-13.2$ & 12.1 & 0.6 \\
\hline Dors & 20.5 & $19.7-25.9$ & 22.8 & 1.6 \\
\hline Anal-fin base length & 19.8 & $19.8-24.3$ & 21.5 & 1.0 \\
\hline Anal-fin lobe length & 15.5 & $14.2-19.4$ & 17.1 & 1.3 \\
\hline Eye to dorsal-fin origin & 38.2 & $35.0-39.5$ & 37.6 & 1.0 \\
\hline Dorsal-fin origin to caudal & 37.6 & $37.4-41.7$ & 39.4 & 1.0 \\
\hline Head length & 28.8 & $27.1-32.5$ & 29.1 & 0.9 \\
\hline \multicolumn{5}{|c|}{ Percents of Head Length } \\
\hline Horizontal eye diameter & 29.4 & 27.4-39.5 & 33.4 & 3.2 \\
\hline Snout length & 26.5 & $21.8-26.8$ & 24.5 & 1.5 \\
\hline Least interorbital width & 28.4 & $23.5-28.4$ & 26.2 & 1.4 \\
\hline Upper jaw length & 42.6 & $38.2-44.6$ & 41.3 & 1.6 \\
\hline
\end{tabular}

projecting anteriorly. Inner row with four $\left(23^{*}\right)$ or five (10) tetra- or pentacuspid* teeth (Figs. 2-3); nine specimens with five teeth on left side bearing four teeth on opposite premaxillary bone. Dentary teeth of c\&s specimens nine (1), 10 (1), or 11 (2). Anterior four (22*) or five (10) dentary teeth largest with four or five* cusps. Premaxillary and dentary teeth massive. Central cusp of all teeth largest. Some specimens with cutting edge of teeth eroded or teeth missing in entire upper and/or lower jaws.

Externally visible dorsal-fin rays ii,9* (one specimen iii,9); first unbranched ray usually less than half length of second unbranched ray. First one preceded by reduced ray only visible at c\&s specimens. First and second branched dorsal-fin rays longest, not reaching adipose fin when adpressed. Dorsalfin origin approximately at middle of SL. Distal margin of dorsal fin nearly straight or slightly convex. Adipose-fin origin located approximately at vertical through insertion of base of last anal-fin ray. Pectoral-fin rays $13(14 *), 14$ (15), or 15 (4), first unbranched; distal margin slightly convex. Tip of adpressed pectoral fin not reaching vertical line passing through dorsal-fin origin, separated from pelvic-fin origin by three or four scale rows. Pelvic-fin rays eight (31) or nine $(2 *)$, first unbranched; distal margin slightly convex. Anal fin with four or five unbranched and 16 (1), 17 (2), 18 (8*), 19 (15), 20 (6), or 21 (1) branched rays. First (2) and second (2) unbranched anal-fin rays only observed in cleared and stained specimens. Anterior branched rays longest. Distal margin of anal fin nearly straight to concave. Anal-fin origin located approximately at vertical through one to three scales behind base of posterior most dorsal-fin ray. Principal caudal-fin rays i,17,i. Dorsal procurrent caudal-fin rays 11 (2) or 12 (2). Ventral procurrent caudal-fin rays 10 (2) or 11 (2). Caudal fin forked, upper and lower lobes approximately equal in size.

Scales cycloid. Circuli on posterior field of scales present. Predorsal medial scales 12 (1), 13 (6*), 14 (19), or 15 (7), sometimes in irregular series. Lateral line complete with 39 (9), $40\left(15^{*}\right)$, or $41(9)$ scales. Seven (16) or eight $\left(16^{*}\right)$ scales in transverse series above lateral line. Five (32*) or six (1) scales in transverse series below lateral line. Single row of five (1), six (6), seven (15*), eight (7), nine (3), or 11 (1) scales covering basis of anterior most anal-fin rays. Circumpeduncular scales 16 (18*), 17 (8), 18 (4), or 19 (1). Caudal fin not scaled.

Third infraorbital small, not in contact with preopercle. First gill arch with seven epibranchial, nine ceratobranchial, and one hypobranchial setiform gill-rakers. One gill-raker at joint of epi- and ceratobranchial bones. Four branchiostegal rays. Total number of vertebrae 38 (four weberian +13 (1) or 14 (3) thoracic +20 caudal). Thirteen (1) or 14 (3) pairs of pleural ribs. Supraneurals five (4). Breeding tubercles minute, visible only in few specimens as scarce white bumps scattered over top of head, face, predorsal scales and some flank scales from anterior portion of trunk.

Color in alcohol. Preserved specimens with overall ground color yellowish. Guanine pigmentation present on opercular and infraorbital series, and over most of flank scales from midlateral dark stripe to below. Body covered by scattered dark chromatophores, more concentrated on distal margin of scales forming a reticulated pattern. Dorsal and dorsolateral portions of head and body dark brown. Lateral region of the head densely covered by dark chromatophores, less concentrated on third infraorbital and below it, and over laminar portion of opercle and subopercle. Lower lip dark brown. Ventral regions of head and abdomen light. Black humeral spot conspicuous, narrow and vertically elongated; two or two and a half scales wide and about six scales high. Midlateral dark stripe extending from humeral region to median caudal-fin rays, about two to four (usually three) scales far from humeral spot. Anterior portion of midlateral stripe vertically expanded, about three scales high, gradually decreasing to one scale high in caudal peduncle at vertical through insertion of base of last anal-fin ray. Its anterior region a bit darker than remaining, insinuating a faint second humeral spot in few specimens. Terminal portion of midlateral stripe at caudal peduncle irregularly expanded forming an inconspicuous caudal spot extending over caudalfin base. Midlateral stripe faint over medial caudal-fin rays in larger specimens, more visible at small fish. All fins, except adipose fin, reddish to orange with distal margin hyaline and scattered dark chromotophores, more concentrated on its distal margins. Adipose fin yellowish as background color of body with dark chromatophores mainly on its base. 


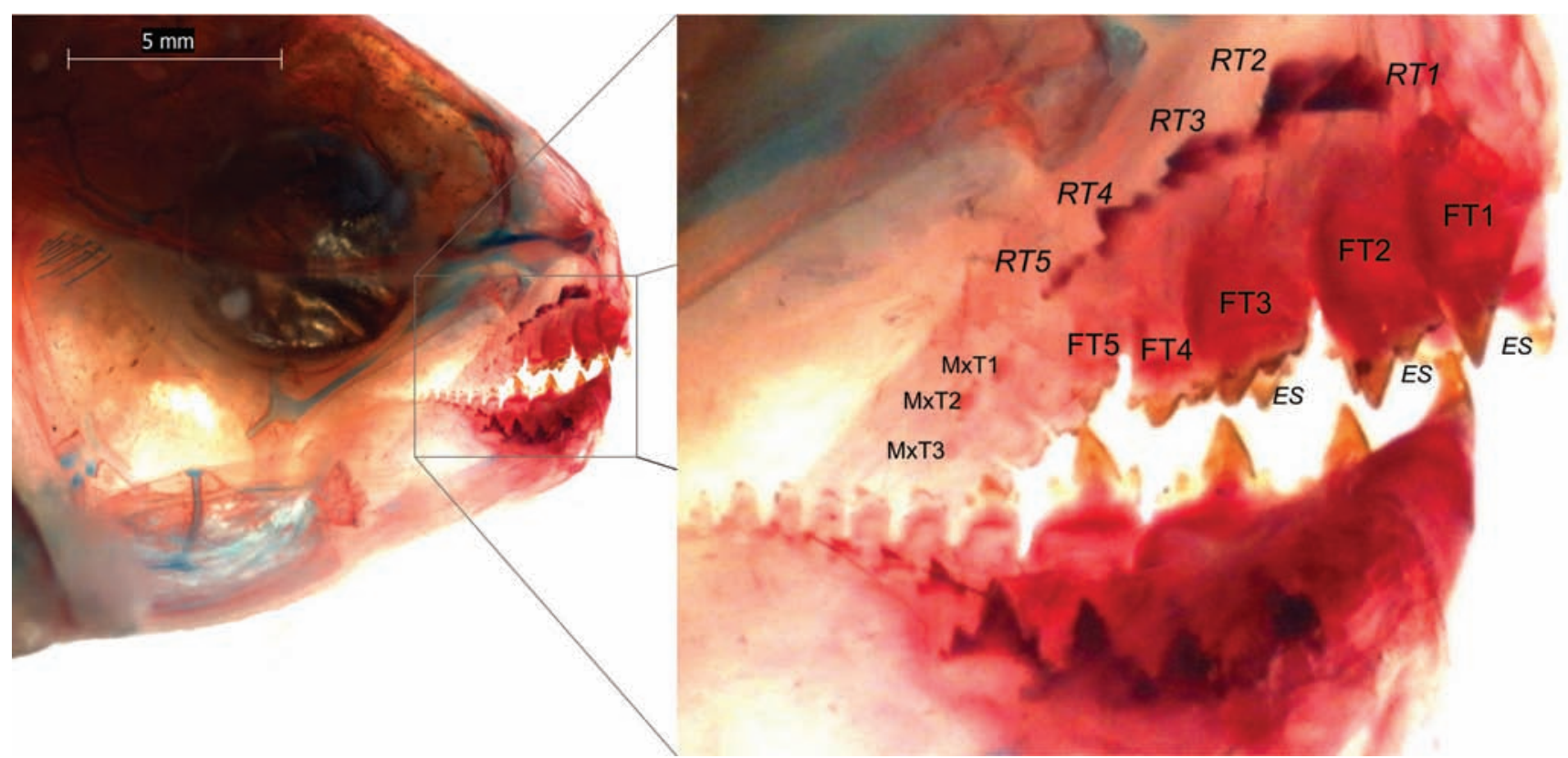

Fig. 2. Astyanax eremus, new species, MCP 46942 (71.9 mm SL), paratype. Medial view of left side of the head with mouth region enhanced. Tooth of the outer premaxillary row (ES). Functional tooth of the inner premaxillary row (FT). Tooth of the maxillary bone (MxT). Replacement tooth of the inner premaxillary series (RT).

Color in life. Color in life is similar to that in preserved specimens but more silvery, stronger red pigmentation, and lateral spots and midlateral stripe less evident.

Sexual dimorphism. Secondary sexual characters were not found on examined specimens. Occasional nuptial tubercles were not associated to sex herein.

Habitat and ecological notes. Astyanax eremus inhabits the rio Canivete, a small, short and isolated tributary to the main channel of the upper rio Iguaçu, at Balsa Nova county. Rio Canivete runs through a grove of about $1,000 \mathrm{~m}$ long and $150 \mathrm{~m}$ wide, where the sampling point is located. This woodland, which is more or less well preserved with native and introduced marginal vegetation, mainly formed by trees (including Brazilian pine Araucaria angustifolia (Bertol.)) and bushes, is somewhat an island inside a wheat plantation. It is bounded upstream by a fall of about $10 \mathrm{~m}$, and downstream by a series of rapids for about 1,000 $\mathrm{m}$ which form a gap of more than $35 \mathrm{~m}$ from the sampling area up to the rio Iguaçu ledge. The sample site was inside the grove and had about 0.5-1.0 $\mathrm{m}$ depth and about $5 \mathrm{~m}$ width, with lentic transparent water and sandy and clay bottom variably covered by fallen trees, branches and leaves (Fig. 4). No other fish species was collected at the sample area of $A$. eremus.

Macroscopical observation of gonads extracted from the four c\&s specimens indicates that $A$. eremus was at reproductive season during the collect period (October). Two of the specimens where mature females, with ovaries full of ovocytes (71.9 and $76.9 \mathrm{~mm} \mathrm{SL})$. One of the specimens was a mature male with large testicles $(61.8 \mathrm{~mm} \mathrm{SL})$. The smaller specimen (44.6 mm SL) was immature and its sex could not be identified. It was not possible to associate the scarse and underdeveloped observed tubercles to sexual dimorphism.

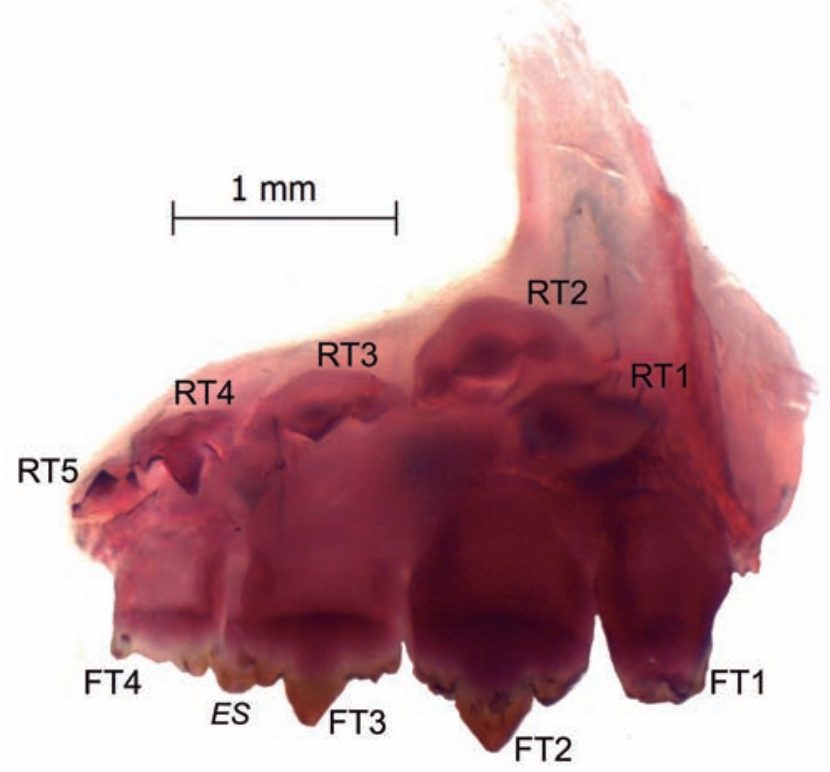

Fig. 3. Astyanax eremus, new species, MCP 46942, $71.9 \mathrm{~mm}$ SL, paratype. Posterior view of the left premaxillary bone. Tooth of the outer premaxillary row (ES). Functional tooth of the inner premaxillary row (FT). Replacement tooth of the inner premaxillary series (RT). 


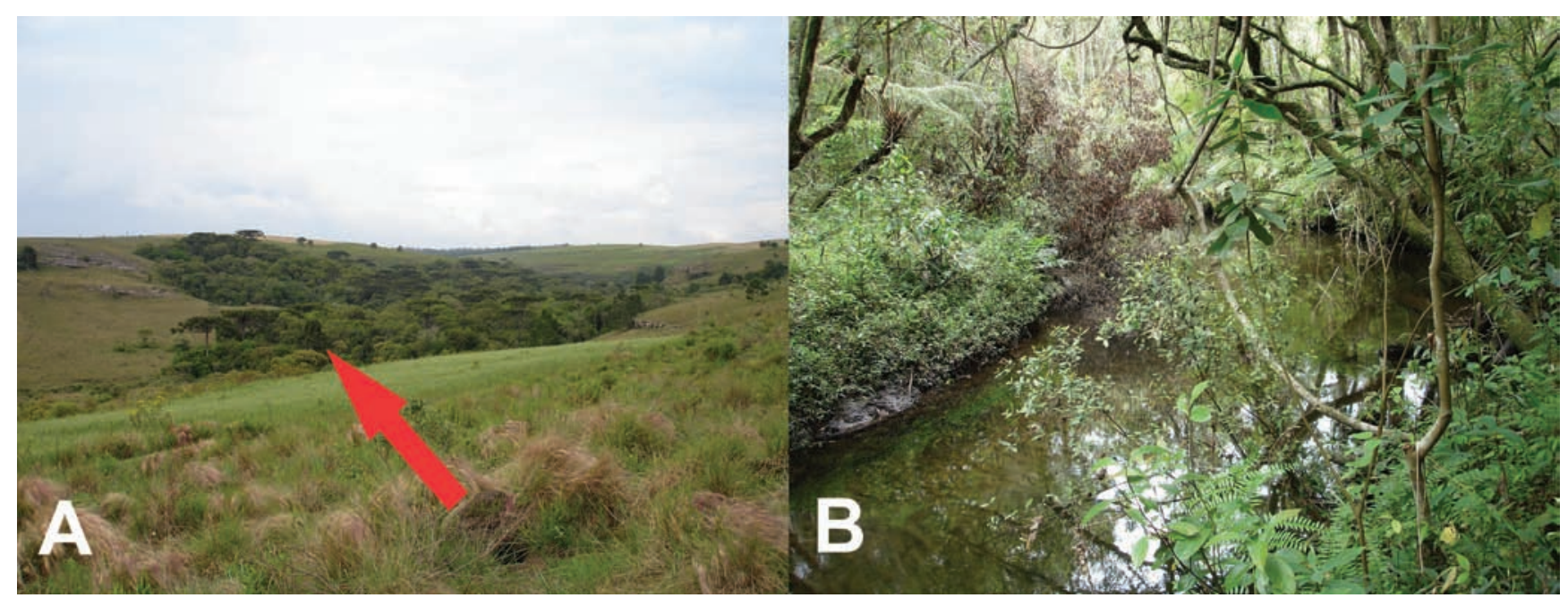

Fig. 4. Type locality of Astyanax eremus, new species, Amola Faca/Registro Farm, Balsa Nova, Paraná (A: panoramic view of the type locality; B: sample site). Red arrow indicates the sample area.

Distribution. Astyanax eremus is known from its type locality (Fig. 5) in the rio Canivete, a small and short isolated affluent of the upper rio Iguaçu, a tributary to the rio Paraná drainage.

Etymology. From the Latin eremus, that means "alone" or "uninhabited", in allusion to the absence of other fish species in the type locality. An adjective.

\section{Discussion}

Astyanax is a highly diverse and taxonomically complex genus and its taxonomy and relationships seems to be far from a reasonable understanding. The diagnostic combination of characters proposed by Eigenmann $(1921,1927)$ to distinguish Astyanax from other genera of the Characidae is very variable and presents great overlap. These problems are more evident distinguishing Astyanax from Hemigrammus Gill, Bryconamericus Eigenmann, Moenkhausia Eigenmann, and Hyphessobrycon Durbin. As a practical example, according to Eigenmann $(1921,1927)$ Astyanax is distinguished from Bryconamericus mainly by the presence of five inner premaxillary teeth (vs. four teeth) and reduced size of the third infraorbital bone, which is not in contact with the preopercle (vs. expanded third infraorbital in contact with preopercle). Nevertheless, these characters are not exclusive from Astyanax and are widely distributed and variable among characid genera.

Malabarba \& Weitzman (2003) hypothesized a monophyletc group ("Clade A") in which Bryconamericus was included, but not Astyanax. Members of this clade were characterized by the presence of hooks on fin rays, absence of supraorbital, presence of two unbranched plus eight branched dorsal fin rays, and presence of four teeth in the inner premaxillary row. This clade was latter supported by molecular and morphological phylogenetic studies (Calcagnoto et al.,
2005; Mirande, 2009, 2010; Oliveira et al., 2011), being redefined as Stevardiinae by Mirande (2009). According to Mirande (2010), Stevardiinae is diagnosed by the presence of three synapomorphies: absence of epiphyseal branch of supraorbital canal, eight or fewer branched dorsal-fin rays, and nine pterygiophores at dorsal fin. Once Astyanax eremus does not present such synapomorphies, the new species should not be included in Stevardiinae. However, A. eremus presents subterminal mouth, at least in adults, and the frequent occurrence of four teeth at inner premaxillary series (or the polymorphic state of four teeth on one side and five on the opposite), which are characters shared with some genera of Stevardiinae, as Bryconamericus and Hypobrycon, what is herein interpreted as homoplasies.

Astyanax eremus demonstrates that the number of teeth from the inner premaxillary row, one of the characters used by Eigenmann to differentiate Astyanax and Bryconamericus (Eigenmann, 1921, 1927; Malabarba \& Weitzman, 2003; Mirande, 2009, 2010), may vary even intraspecifically. Differently from most of Astyanax species, approximately $70 \%$ of the specimens of $A$. eremus bear four teeth, rather than five, at the inner premaxillary teeth row. Nine specimens of $A$. eremus bear five teeth on left premaxillary bone and four teeth on the opposite bone. Two of these asymmetrical specimens were cleared and stained, but revealed no morphological difference among left and right premaxillary bones. The only difference among all examined specimens concerns to the number of teeth, where the fifth tooth is smaller than the remaining four, and is attached at the lateral tip of the premaxillary bone. In some of the alcohol preserved specimens the two or three lateral teeth seems to be close to each other in the bone, what was also observed in one of the c\&s specimens. In one of the four/five teeth c\&s specimens (MCP 46942, 71.9 $\mathrm{mm} \mathrm{SL}$ ) the right premaxillary bone bears five replacement 


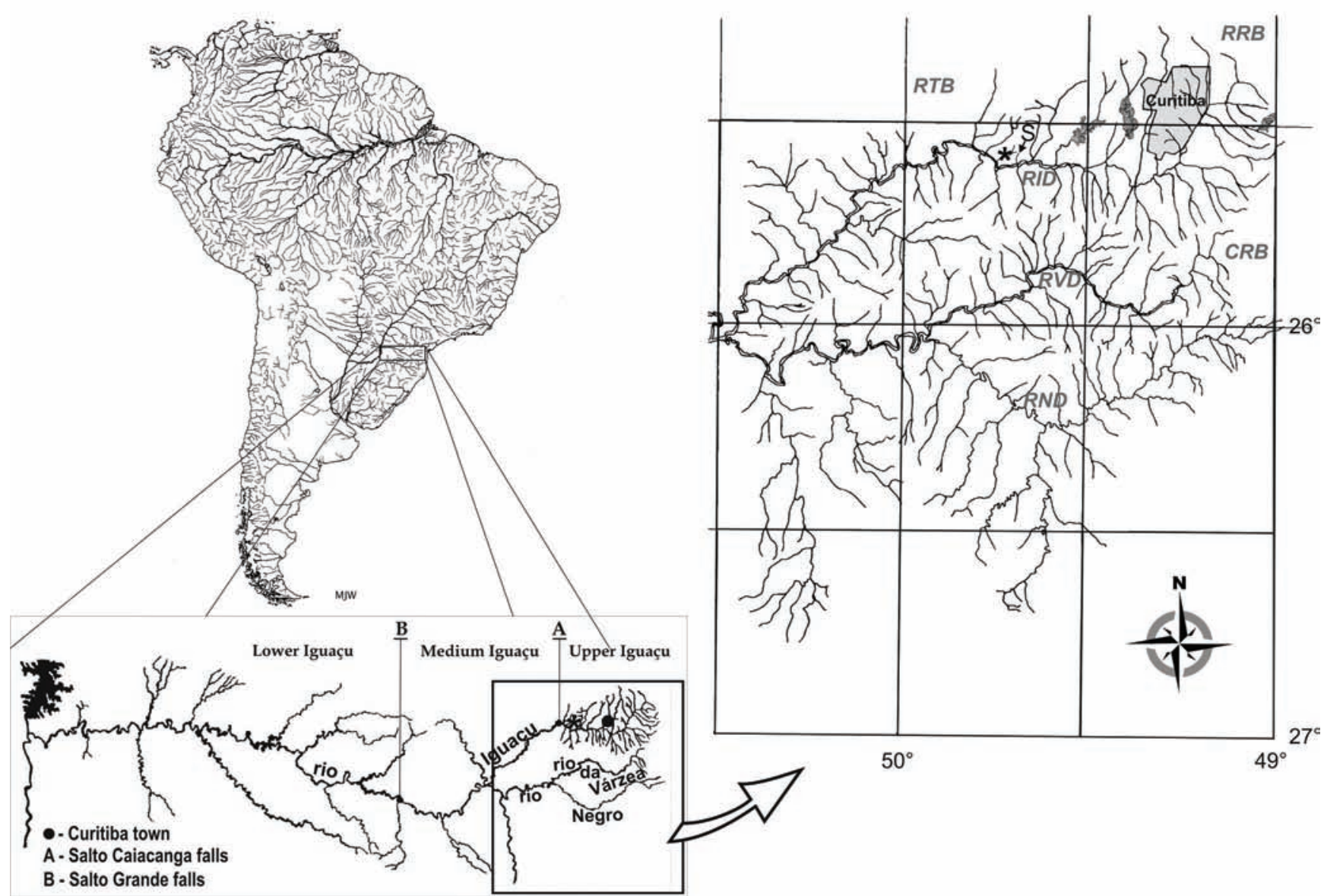

Fig. 5. Distribution of Astyanax eremus, new species, in rio Iguaçu basin $\left(^{*}\right)$. Vertical bars indicate biogeographic barriers of the rio Iguaçu according to Ingenito et al. (2004) (A and B). Serrinha from Haseman \& Eigenmann (1911) (S). Coastal Atlantic rivers from Southeastern Brazil (CRB). Rio Iguaçu drainage (RID). Rio Negro drainage (RND). Rio Ribeira de Iguape drainage (RRB). Rio Tibagi drainage (RTB). Rio da Várzea drainage (RVD).

teeth, but has no space for the fifth functional tooth (Fig. 3), while the opposite bone (left side) has congruent number of functional and replacement teeth (five teeth). The other c\&s specimen with polymorphic premaxillary dentition (MNRJ 39678, $44.6 \mathrm{~mm} \mathrm{SL}$ ) bear the same number of functional and replacement teeth in each premaxillary bone (five at left and four at right side). One of the c\&s specimens (MCP 46942, $61.8 \mathrm{~mm} \mathrm{SL}$ ) bears five functional and four replacement teeth in both premaxillary bones (Fig. 2). The last c\&s specimen (76.2 $\mathrm{mm} \mathrm{SL}$ ) bears four functional and replacement teeth in both premaxillary bones (Fig.2).

Variable or asymmetrical number of teeth in the inner premaxillary row fluctuating from four to five has already been reported for some Astyanax in literature, including original descriptions: A. albeolus Eigenmann, A. festae (Boulenger), A. metae Eigenmann, A. regani Meek, A. rivularis, according to Eigenmann (1921); A. paranahybae Eigenmann, according to Garutti \& Britski (2000); A. leonidas and A. troya (according to the original description in Azpelicueta et al., 2002); A. aeneus (Günther), A. rutilus (Jenyns), and A. obscurus (Hensel), according to Melo \& Buckup (2006); A. burgerai (according to the original description in Zanata \& Camelier, 2009); A. turmalinensis (according to Triques \& Queiroz, 2010); and A.bifasciatus Garavello \& Sampaio, 2010 (according to the original description). Among Bryconamericus species this variation was reported for B. pyahu Azpelicueta, Casciotta \& Almirón (according to original description in Azpelicueta et al., 2003); B. orinocensis and B. singularis Román-Valencia (according to Román-Valencia et al., 2008), B. cf. rubropictus (according to Mirande, 2010). Mirande (2010) also lists its occurrence in Cyanocharax alburnus (Hensel, 1870), Diapoma terofali (Géry, 1964) and Hemibrycon surinamensis Géry, 1962.

Although the number of inner premaxillary teeth seems to be variable in some Characidae, Mirande (2010) successfully used the decrease of teeth number in the inner premaxillary row as one of the synapomorphies of this unnamed Node 198, which contains Aphyocharacinae, Aphyoditeinae, Cheirodontinae, Gymnocharacinae, Stevardiinae, and Bryconamericus scleroparius, demonstrating its phylogenetic validity as a suprageneric character. This author performed the 
most complete phylogenetic analysis of this character up to now, but its relevance was not adequately tested, as indicated by himself (Mirande, 2010: 423), what denote the need of a detailed review of its occurrence and phylogenetic importance among Characidae's members.

Astyanax eremus was discovered in an isolated habitat from other syntopic species of fish, what can result in a less selective pressure, as well as an increase of possible expressions of plastic phenotypes (=characters) and/or polymorphic genes (Schlichting \& Pigliucci, 1998). Such expressions may be represented in structures as cheek muscles development or different numbers of teeth, dynamic aspects directly linked to the life history of the species that suffer great selective pressure (Smits et al., 1996a; Smits et al., 1996b), and could represent here a case of "ecological release" (Begon et al., 2005). This feature may be represented here by a frequency increase of a character that can be naturally variable promoting a more complete trophic exploration. Such variability may be not observed, or may be statistically irrelevant, in other places due to ecological constraints of more competitive environments. Moreover, the evolutionary process trend to drive characters to reductive states in structures as number of skull bones and number of teeth (Romer \& Parsons, 1985), what support the hypothesis of Malabarba \& Weitzman (2003) and Mirande (2010) about the presence of four teeth in the inner premaxillary row be interpreted as a derived character-state within Astyanax. The observation of this kind of structural reduction reinforces its "plastic potential" (homoplasy), although for practical identification of characid genera this character still being usefulness, considering its exceptions.

The rio Iguaçu basin comprises 14 valid species of Astyanax, including the new one herein described: $A$. altiparanae Garutti \& Britski; A. bifasciatus; A. dissimilis Garavello \& Sampaio; A. gymnodontus (Eigenmann); A. gymnogenys; A. ita; A. jordanensis Alcaraz, Pavanelli \& Bertaco; A. leonidas; A. longirhinus Garavello \& Sampaio; A. minor Garavello \& Sampaio; A. serratus; A. totae; A. varzeae, and $A$. eremus. A synopsis on the taxonomic knowledge about Astyanax species from the rio Iguaçu is available in Garavello et al. (1997) and Garavello \& Sampaio (2010) and will not be reproduced here. Although Azpelicueta et al. (2002: 249) informed at the original description of A. leonidas that this species occurs in rio Iguaçu (Iguazú), at Misiones (Argentina), Garavello \& Sampaio (2010) did not included that species in their comments or analysis.

Ingenito et al. (2004) proposed limits for biogeographical regions of the rio Iguaçu basin and listed the presence of six species of Astyanax in its upper portion. Five of those species were considered new species at that time and were later described ("Astyanax sp. B" = A. bifasciatus, "Astyanax sp. $\mathrm{C} "=$ A. minor, "Astyanax sp. D" = A. serratus, "Astyanax sp. $\mathrm{E} "=$ A. dissimilis, and "Astyanax sp. n." = A. totae). Sampaio
\& Garavello (2010) recently informed that part of the type specimens of A. paranae from Porto União da Vitória (actually Porto União and União da Vitória cities) and Serrinha were composed by specimens of A. gymnogenys. Once Serrinha is located in the upper rio Iguaçu basin, very close to the boundary of its upper and medium sections ( $25^{\circ} 35^{\prime} 55.9^{\prime \prime} \mathrm{S} 49^{\circ} 42^{\prime} 45.0^{\prime \prime} \mathrm{W}$, Fig. 5), A. paranae sensu Eigenmann (1927) and A. gymnogenys may be assigned to both middle and upper portions of the river basin. Despite of this new information given by Garavello \& Sampaio (2010), they did not make it clear if all type specimens of A. paranae from the rio Iguaçu are A. gymnogenys or just some. They also did not measure those specimens and did not left clear the reasons to take that decision. As Garutti \& Britski (2000) restricted the type locality of A. paranae to Castro, rio Tibagi drainage, and Garavello \& Sampaio (2010) did not inform the exactly number or size of comparative material analyzed by them, it is difficult to take any conclusions about the presence or synonymies of Astyanax paranae in the rio Iguaçu without examination of the original specimens studied by Eigenmann (1914, 1921, 1927).

Although Garavello \& Sampaio (2010) did not indicate relationships among the species studied by them with existing species groups, analysis of specimens of $A$. serratus let us to allocate that species in the A. scabripinnis species complex. Otherwise, we had no access to specimens of A. gymnogenys during our studies, but we tentatively assign that species to A. scabripinnis species complex. Our decision is based on information given by Garavello \& Sampaio (2010: 853) about the mix of species in the type series of Astyanax scabripinnis paranae from the rio Iguaçu and morphological characters of A. gymnogenys: shallow body depth (35.7-39.0\% of SL), low number of branched anal-fin rays (18-20 rays), and color pattern (midlateral dark stripe extending to end of caudal-fin rays).

The rio Iguaçu basin is known by its high ichthyofaunistic endemism (Haseman, 1911; Garavello et al., 1997; Ingenito et al., 2004; Baumgartner et al., 2006; Ingenito et al., 2008; Alcaraz et al., 2009; Abilhoa \& Duboc, 2007; Garavello \& Sampaio, 2010), especially concerning to genus Astyanax (Pavanelli \& Oliveira, 2009). Among the 14 species of Astyanax reported from the rio Iguaçu basin, 13 are endemic to the basin, with some of them only occurring in smaller sub-basins (e.g.: A. totae, A. varzeae, A. jordanensis, A. ita, and A. eremus). According to our observations, "Astyanax sp. F." proposed by Sampaio (1988) and Garavello et al. (1997) include different species of Astyanax from all portions of the rio Iguaçu basin. At least two described species fits on the species delimitation of "Astyanax sp. F." proposed by those authors: A. varzeae and A. gymnodontus (see Pavanelli \& Oliveira, 2009 for comments on A. gymnodontus). The new species herein described also seems to fit to the feeble definition of "Astyanax sp. F", what lead us to think that more new species, possibly restricted to small tributaries, are currently included in it. 
Comparative material. Brazil. Astyanax laticeps: MCP 20548, 7, Rio Grande do Sul, Pedro Osório, stream at the road Pedro Osório/Basílio, laguna dos Patos system. MCP 21785, 3, Santa Catarina, Rio dos Cedros, rio Palmeira, affluent of rio Itajaí-Açu. MCP 40983, 1, Rio Grande do Sul, Bento Gonçalves, córrego Paco, affluent of rio Jacuí. Astyanax paranae: MHNCI 8138, 11, Paraná, Castro, rio Iapó, afluente of rio Tibagi. Astyanax serratus: MHNCI 9095, 2, Paraná, Araucária, stream in Chácara Kotowski, PR-423, affluent of rio Iguaçu. MHNCI 9124, 4, Paraná, Balsa Nova, affluent of rio Corisco at the road Balsa Nova/Engenheiro Bley, tributary of rio Iguaçu. MHNCI 9153, 6, Paraná, Lapa, Engenheiro Bley Railroad Station, rio Iguaçu basin. Astyanax totae: MHNCI 10305, holotype; MHNCI 10306, 21 paratypes, Paraná, Balsa Nova, rio Cascata, tributary of rio Tortuoso, affluent of rio Iguaçu. Astyanax varzeae: MHNCI 11688, holotype; MHNCI 9147, 15 paratypes, Paraná, Tijucas do Sul, rio São João, tributary of rio Negro, affluent of rio Iguaçu. Bryconamericus exodon: MZUSP 90452, 5, Mato Grosso, Cáceres, rio Sepotuba, affluent of rio Paraguay. Bryconamericus ikaa: MNRJ 27296, 10, Santa Catarina, Porto União, rio Iguaçu. Bryconamericus iheringii: DZSJRP 5452, 3, Santa Catarina, Volta Grande, small stream tributary to rio Preto, affluent of rio Iguaçu. DZSJRP 5461, 2, Paraná, Porto Vitória, rio Espingarda, tributary to rio Areia, affluent of rio Iguaçu.

\section{Acknowledgments}

For the loan of specimens we are indebted to Carlos A. S. Lucena (MCP), Francisco Langeani (DZSJRP), Osvaldo T. Oyakawa (MZUSP), and Vinicius Abilhoa (MHNCI). We are grateful to César Román-Valencia (IUQ), Francisco Langeani (DZSJRP) and Mahmoud Mehana (UNESP) for provide bibliographies. We are also greateful to Vinicius A. Bertaco (MCN/FZB) for provide additional information about some of the species from Astyanax scabripinnis species complex. The authors are thankful to Francisco Langeani, Juan Marcos Mirande (CONICET) and two anonymous reviewers for suggestions for the improvement of the manuscript. Bruno Leite Neves, owner of the Amola-Faca/Registro Farm provided information about the collect area, contact with other farmers, guided us and helped us during field works. Gislaine Otto (UFPR) helped us in field works. Samples were made under IBAMA/MMA collecting permit number 10320-1. This study was supported by grants from Conselho Nacional de Desenvolvimento Científico e Tecnológico (CNPq, Projeto CT-HIDRO, Procs. 563889/2005-5 to MHNCI and 373194/2008-0 to LFSI; Proc. 350672/2011-3 post-doctoral fellowship -DCR- to LFSI), and Fundação Estadual de Amparo à Pesquisa do Estado do Espírito Santo (FAPES, Proc. 53132203/2011, post-doctoral -DCR- fellowship to LFSI).

\section{Literature Cited}

Abilhoa, V. \& L. F. Duboc. 2007. A new species of the freshwater fish genus Astyanax (Ostariophysi: Characidae) from the rio Iguaçu basin, southeastern Brazil. Zootaxa, 1587: 43-52.

Alcaraz, H. S. V., C. S. Pavanelli \& V. A. Bertaco. 2009. Astyanax jordanensis (Ostariophysi: Characidae), a new species from the rio Iguaçu basin, Paraná, Brazil. Neotropical Ichthyology, 7: 185-190.

Azpelicueta, M. M., J. R. Casciota \& A. E. Almirón. 2002. Two new species of the genus Astyanax (Characiformes, Characidae) from the Paraná river basin in Argentina. Revue suisse de Zoologie, 109: 243-259.

Azpelicueta, M. M., J. R. Casciota \& A. E. Almirón. 2003. Bryconamericus pyahu sp. n. (Characiformes, Characidae), a new species from río Iguazú basin, in Argentina. Revue suisse de Zoologie, 110: 581-589.

Baumgartner, D., G. Baurmgartner, C. S. Pavanelli, C. S., P. R. L. Silva, V. A. Frana, L. C. Oliveira \& M. R. Michelon. 2006. Fish, Salto Osório Reservoir, Iguaçu River basin, Paraná State, Brazil. Check List, 2: 1-4.

Begon, M., C. R. Townsend \& J. L. Harper. 2005. Ecology : from individuals to ecosystems. Fourth edition. Malden, Blackwell Publishing.

Bertaco, V. A., F. R. Carvalho \& F. C. Jerep. 2010. Astyanax goyanensis (Miranda-Ribeiro, 1944), new combination and Astyanax courensis, new species (Ostariophysi: Characiformes): two Characidae from the upper rio Tocantins basin, Central Brazil. Neotropical Ichthyology, 8: 265-275.

Bertaco, V.A. \& C. A. S. Lucena. 2006. Two new species of Astyanax (Ostariophysi: Characiformes: Characidae) from eastern Brazil, with a synopsis of the Astyanax scabripinnis species complex. Neotropical Ichthyology, 4: 53-60.

Bertaco, V. A. \& C. A. S. Lucena. 2010. Redesciption of Astyanax obscurus (Hensel, 1870) and A. laticeps (Cope, 1894) Teleostei: Characidae): two valid freshwater species originally described from rivers of Southern Brazil. Neotropical Ichthyology, 8: 7-20.

Bertaco, V. A \& L. R. Malabarba. 2001. Description of two new species of Astyanax (Teleostei: Characidae) from headwater streams of Southern Brazil, with comments on the "A. scabripinnis species complex". Ichthyological Exploration of Freshwaters, 12: 221-234.

Calcagnotto, D., S. A. Shaefer \& R. DeSalle. 2005. Relationships among characiform fishes inferred from analysis of nuclear and mitochondrial gene sequences. Molecular Phylogenetics and Evolution, 36: 135-153.

Eigenmann, C. H. 1914. Some results from studies of South American fishes. IV. New genera and species of South American fishes. Indiana University Studies, 20: 44-48.

Eigenmann, C. H. 1921. The American Characidae. Memoirs of the Museum of Comparative Zoology, 43: 209-310.

Eigenmann, C. H. 1927. The American Characidae. Memoirs of the Museum of Comparative Zoology, 43: 311-428.

Eschmeyer, W. N. \& R. Fricke. (Eds.). 2013. Catalog of Fishes electronic version. Available from: http://researcharchive.calacademy.org/ research/Ichthyology/catalog/fishcatmain.asp (31 January 2013).

Fink, W. L. \& S. H. Weitzman. 1974. The so-called cheirodontin fishes of Central America with description of two new species (Pisces, Characidae). Smithsonian Contributions to Zoology, 172: 1-46.

Garavello, J. C., C. S. Pavanelli \& H. I. Suzuki. 1997. Caracterização da ictiofauna do rio Iguaçu. Pp. 61-84. In: Agostinho, A. A. \& L. C. Gomes. Reservatório de Segredo: bases ecológicas para o manejo. Maringá, Eduem. 
Garavello, J. C. \& F. A. A. Sampaio. 2010. Five new species of genus Astyanax Baird \& Girard, 1854 from Rio Iguaçu, Paraná, Brazil (Ostariophysi, Characiformes, Characidae). Brazilian Journal of Biology, 70: 847-865.

Garutti, V. \& H. A. Britski. 2000. Descrição de uma espécie nova de Astyanax (Teleostei: Characiformes) da bacia do Alto Rio Paraná e considerações sobre as demais espécies do gênero na bacia. Comunicações do Museu de Ciências e Tecnologia da PUCRS, Sér. Zoologia, 13: 65-88.

Haseman, J. D. 1911. Some new species of fishes from the Rio Iguassú. Annals of the Carnegie Museum, 7: 374-387.

Haseman, J. D. \& C. H. Eigenmann. 1911. A brief report upon the expedition of the Carnegie Museum to Central South America. Together with a list of localities at which Mr. Haseman collected. Annals of the Carnegie Museum, 7: 287-314.

Ingenito, L. F. S., L. F. Duboc \& V. Abilhoa. 2004. Contribuição ao conhecimento da ictiofauna da bacia do alto rio Iguaçu, Paraná, Brasil. Arquivos de Ciências Veterinárias e Zoologia da UNIPAR, 7: 23-36.

Ingenito, L. F. S., M. S. Ghazzi, L. F. Duboc \& V. Abilhoa. 2008. Two new species of Rineloricaria (Siluriformes: Loricariidae) from the rio Iguaçu basin, southern Brazil. Neotropical Ichthyology, 6: 355-366.

Javonillo, R., L. R. Malabarba, S. H. Weitzman \& J. R. Burns. 2010. Relationships among major lineages of characid fishes (Teleostei: Ostariophy.si: Characiformes), based on molecular sequence data. Molecular Phylogenetics and Evolution, 54: 498-511.

Lima, F. C. T., L. R. Malabarba, P. A. Buckup, J. F. P. da Silva, R. P. Vari, A. Harold, R. Benine, O. T. Oyakawa, C. S. Pavanelli, N. A. Menezes, C. A. S. Lucena, M. C. S. L. Malabarba, Z. M. S. de Lucena, R. E. Reis, F. Langeani, L. Casatti, V. A. Bertaco, C. Moreira \& P. H. F. Lucinda. 2003. Genera incertae sedis in Characidae. Pp. 106-169. In: Check list of the freshwater fishes of South and Central America. Reis, R. E., S. O. Kullander \& C. Ferraris Jr. (Eds.). Porto Alegre, Edipucrs.

Malabarba, L. R. \& S. H. Weitzman. 2003. Description of a new genus with six new species from southern Brazil, Uruguay and Argentina, with a discussion of a putative characid clade (Teleostei: Characiformes: Characidae). Comunicações do Museu de Ciências e Tecnologia da PUCRS, Sér. Zoologia, 16: 67-151.

Marinho, M. M. F. \& F. C. T. Lima. 2009. Astyanax ajuricaba: a new species from the Amazon basin in Brazil (Characiformes: Characidae). Neotropical Ichthyology, 7: 169-174.

Melo, F. A. G. 2001. Revisão taxonômica das espécies do gênero Astyanax Baird \& Girard, 1854 (Teleostei: Characiformes: Characidae) da região da Serra dos Órgãos. Arquivos do Museu Nacional, 59: 1-46.

Melo, F. A. G. \& P. A. Buckup. 2006. Astyanax henseli, a new name for Tetragonopterus aeneus Hensel, 1870 from southern Brazil (Teleostei: Characiformes). Neotropical Ichthyology, 4: 45-52.

Mirande, J. M. 2009. Weighted parsimony phylogeny of the family Characidae (Teleostei: Characiformes). Cladistics, 25: 574-613.

Mirande, J. M. 2010. Phylogeny of the family Characidae (Teleostei: Characiformes): from characters to taxonomy. Neotropical Ichthyology, 8: 385-568.

Moreira-Filho, O. \& L. A. C. Bertollo. 1991. Astyanax scabripinnis (Pisces, Characidae): a species complex. Revista Brasileira de Genética, 14: 331-357.
Oliveira, C., G. S. Avelino, K. T. Abe, T. C. Mariguela, R. C. Benine, G. Ortí, R. P. Vari \& R. M. C. Castro. 2011. Phylogenetic relationships within the speciose family Characidae (Teleostei: Ostariophysi: Characiformes) based on multilocus analysis and extensive ingroup sampling. BMC Evolutionary Biology, 11: 1-25.

Pavanelli, C. S. \& C. A. M. Oliveira. 2009. A redescription of Astyanax gymnodontus (Eigenmann, 1911), new combination, a polymorphic characid fish from the rio Iguaçu basin, Brazil. Neotropical Ichthyology, 7: 569-578.

Potthoff, T. 1984. Clearing and staining techniques. Pp. 35-37. In: Moser, H. G., W. J. Richards, D. M. Cohen, M. P. Fahay, A. W. Kendall Jr. \& S. L. Richardson (Eds.). Ontogeny and systematics of fishes. American Society of Ichthyologists and Herpetologists, Special Publication Number 1. Lawrence, Allen Press.

Román-Valencia, C., D. C. Taphorn \& R. I. Ruiz-C. 2008. Two new Bryconamericus: B. cinarucoense n. sp. and B. singularis n. sp. (Characiformes, Characidae) from the Cinaruco River, Orinoco Basin, with keys to all Venezuelan Species. Animal Biodiversity and Conservation, 31: 15-27.

Romer, A. S. \& T. S. Parsons. 1985. The vertebrate body. Sixth Edition. Fort Worth, Saunders College Publishing.

Sampaio, F. A. A. 1988. Estudos taxonômicos preliminares dos Characiformes (Teleostei, Ostariophysi) da bacia do rio Iguaçu, com comentários sobre o endemismo dessa fauna. Unpublished M.Sc. Dissertation. Universidade Federal de São Carlos, São Carlos, 175p.

Schlichting, C. D. \& M. Pigliucci. 1998. Phenotypic evolution: a reaction norm perspective. Sunderland, Sinauer Associates.

Smits, J. D., F. Witte \& G. D. E. Povel. 1996a. Differences between inter- and intraspecific architectonic adaptations to pharyngeal mollusk crushing in cichlid fishes. Biological Journal of the Linnean Society, 59: 367-387.

Smits, J. D., F. Witte \& F. G. Van Veen. 1996b. Functional changes in the anatomy of the pharyngeal jaw apparatus of Astatoreochromis alluaudi (Pisces, Cichlidae), and their effects on adjacent structures. Biological Journal of the Linnean Society, 59: 389-409.

Triques, M. L. \& F. M. Queiroz. 2010. Fish, Characiformes, Characidae, Astyanax turmalinensis Triques, Vono and Caiafa, 2003: distribution extension. Check List, 6: 400-401.

Weitzman, S. H. \& L. R. Malabarba. 1998. Perspectives about the phylogeny and classification of the Characidae (Teleostei: Characiformes). Pp. 161-170. In: Malabarba, L. R., R. E. Reis, R. P. Vari, Z. M. Lucena \& C. A. S. Lucena (Eds.). Phylogeny and Classification of Neotropical Fishes. Porto Alegre, Edipucrs.

Zanata, A. M. \& P. Camalier. 2009. Astyanax vermilion and Astyanax burgerai: new characid fishes (Ostariophysi: Characiformes) from Northeastern Bahia, Brazil. Neotropical Ichthyology, 7: 175-184.

Submitted July 13, 2013 Accepted November 4, 2013 by Francisco Langeani Published June 30, 2014 